\title{
Activated Carbon and Metal Chalcogenide in Applied Materials Research
}

\section{Ho Soonmin*}

Centre for American Education, INTI International University, Malaysia

*Corresponding author: Ho Soonmin, Centre for American Education, INTI International University, Putra Nilai, Negeri Sembilan, Malaysia, Tel: +6067982000; Email: soonmin.ho@ newinti.edu.my

\section{Review Article}

Volume 4 Issue 2

Received Date: July 07, 2020

Published Date: July 21, 2020

\section{Abstract}

Nano material is an important field in world of science and technology. In this work, activated carbon and metal chalcogenide thin films were discussed. Activated carbon has high surface area and porosity structure. Basically, it could be synthesized by using various raw materials under carbonization and chemical activation process. Utilization of activator such as $\mathrm{KOH}$, $\mathrm{NaOH}$, zinc chloride, phosphoric acid, sulphuric acid could improve texture properties and adsorption capacity. On the other hand, metal chalcogenide thin films have been prepared by using various deposition techniques including physical and chemical method. These materials have great potential in solar cell, sensor device, laser device and optoelectronic applications. Characterization of metal sulfide, metal selenide and metal telluride thin films was studied by using different tools.

Keywords: Activated carbon; Activation; Metal chalcogenide; Thin films; Deposition technique

\section{Introduction}

Currently, there are several types of nano materials have been investigated. These materials are produced at very small scale, in the range from 1-100 $\mathrm{nm}$. They show unique properties including electronic, optical and mechanical behaviors based on the results obtained from various characterization tools. Therefore, these materials could be used in various applications such as medical, environmental, solar cell, optoelectronic, sensor and laser devices. Activated carbon could be used as cheap adsorbent to remove heavy metal, dye, pollutants from wastewater [1]. There are many researchers investigate texture characteristics of activated carbon including surface area, microspore diameter distribution and total pore volume [2]. Preparation of activated carbon from different raw materials including agricultural wastes, waste materials [3], food wastes and agricultural by-products because of affordability, local availability [4] and efficiency in removing many pollutants [5]. Chalcogenide metal thin films received great attention due to several unique properties $[6,7]$. Chemical bath deposition, spray pyrolysis, electro deposition, pulsed laser deposition, thermal evaporation, vacuum evaporation, magnetron sputtering, molecular beam epitaxy, metal organic chemical vapour deposition, plasma enhanced chemical vapour deposition, sol gel, spin coating, successive ion layer adsorption and reaction method have been reported by many scientists in order to produce different nanostructured thin films [8-10]. In this work, activated carbon and metal chalcogenide thin films have been discussed. Properties and applications of these nanostructured materials have been reported.

\section{Literature Review}

\section{Activated Carbon}

Surface area and pore characteristics of activated carbon prepared by using various raw materials as indicated in Table 1. Activated carbon has high surface area and high micro porosity structure. It could be produced from various precursors such as agricultural wastes. Activated carbon was synthesized under carbonization and activation process. The activation process could be grouped into physical and 
chemical activation. Carbon dioxide or water stream was used in physical activation. Meanwhile, several types of activator such as zinc chloride, phosphoric acid, sodium hydroxide and potassium hydroxide were employed during chemical activation (Table 2). These activators are considered as cheaper and less corrosion. The obtained carbons could be employed for wastewater treatment since few decades ago. Typically, it could be utilized in different forms such as power, granular and impregnated type. Nowadays, "dye wastewater" produced through human activities and various industries. It must be treated with activated carbon to avoid allergic dermatitis and inhibit sun light penetration in the water. Up-to-date, wastewater treatment in the dye industry could be carried out by using various methods. Generally, food industry, textile industry, paper industry and leather industry contributed to the dye production. Adsorption, solvent extraction, and ion exchange technique were used to remove dye from wastewater. The advantage of each technique was highlighted in Table 2.

\begin{tabular}{|c|c|c|}
\hline Raw Material & Surface Area $\left(\mathrm{m}^{2} / \mathrm{g}\right)$ & Porosity Structure \\
\hline Wheat bran & Surface area was $2543 \mathrm{~m}^{2} / \mathrm{g}$ & $\begin{array}{l}\text { - Activated carbon prepared at } 700^{\circ} \mathrm{C} \text { showed } \\
\text { more micropores. } \\
\text { Activated carbon prepared at } 900^{\circ} \mathrm{C} \text { more } \\
\text { mesoporous [11]. }\end{array}$ \\
\hline $\begin{array}{l}\text { Kanlow } \\
\text { Switchgrass, } \\
\text { Public Miscanthus } \\
\text { biomass }\end{array}$ & $\begin{array}{l}\text { Surface area values are } 783 \text { (Public Miscanthus } \\
\text { biomass) and } 519 \text { (Kanlow Switchgrass) m²/g. }\end{array}$ & $\begin{array}{l}\text { Public Miscanthus biomass: Micropore } \\
\text { volume }=0.24 \mathrm{~cm}^{3} / \mathrm{g}, \text { mesopore volume }=0.17 \\
\mathrm{~cm}^{3} / \mathrm{g}[12] . \\
\text { Kanlow Switchgrass: Micropore volume }=0.18 \\
\mathrm{~cm}^{3} / \mathrm{g}, \text { mesopore volume }=0.07 \mathrm{~cm}^{3} / \mathrm{g} .\end{array}$ \\
\hline Popcorn & Surface area: 2997 to $3074 \mathrm{~m}^{2} / \mathrm{g}$ & $\begin{array}{l}\text { - Micropore and mesopore were produced in } \\
\text { chemical activation in the presence of sodium } \\
\text { hydroxide [13]. } \\
\text { - Total pore volume: } 1.54 \text { to } 2.42 \mathrm{~cm}^{3} \cdot \mathrm{g}^{-1}\end{array}$ \\
\hline Corn cob & $\begin{array}{l}\text { Surface area was found in the range of } 553 \\
\text { to } 1270 \text { for the sample prepared under zinc } \\
\text { chloride as activator. }\end{array}$ & $\begin{array}{l}\text { - } \quad \text { Total pore volume: } 0.29 \text { to } 0.67[14] \text {. } \\
\text { - } \quad \text { Micropore volume: } 0.045 \text { to } 0.28 \text {. }\end{array}$ \\
\hline Mangosteen peel & $\begin{array}{c}\text { Surface area is } 1621 \text { for the sample prepared } \\
600^{\circ} \mathrm{C}, 30 \text { minutes, } 1: 4 \text { impregnation ratio } \\
\left(\mathrm{ZnCl}_{2} \text { solution). }\right.\end{array}$ & $\begin{array}{l}\text { - Total pore volume was } 1.8 \mathrm{~cm}^{3} / \mathrm{g} \text { for the sample } \\
\text { prepared at optimized conditions [15]. }\end{array}$ \\
\hline $\begin{array}{l}\text { Peach, coconut, } \\
\text { apricot }\end{array}$ & $\begin{array}{l}\text { Coconut: } 1101 \\
\text { Apricot: } 819 \\
\text { Peach: } 793\end{array}$ & $\begin{array}{l}\text { - } \quad \text { Coconut: micropore volume is } 0.24 \text { [16]. } \\
\text { - } \text { Apricot: micropore volume is } 0.184 . \\
\text { - } \quad \text { Peach: micropore volume is } 0.206 .\end{array}$ \\
\hline Tabah bamboo & $\begin{array}{l}\text { Surface area was increased from } 50.45,108.5 \\
\text { to } 210 \mathrm{~m}^{2} / \mathrm{g} \text { with increasing the activation time } \\
(50,100 \text { and } 150 \text { minutes })\end{array}$ & $\begin{array}{l}\text { Total pore volume increases }(0.059,0.089 \text { and } \\
0.09) \text { as the activation time was increased [17]. }\end{array}$ \\
\hline Palimera sprout & $\begin{array}{l}\text { Surface area was } 2090 \mathrm{~m}^{2} / \mathrm{g} \text { in the presence of } \\
\mathrm{KOH}\end{array}$ & - Total pore volume is $1.44 \mathrm{~cm}^{3} / \mathrm{g}$ [18]. \\
\hline Slash pine wood & $979-1185 \mathrm{~m}^{2} / \mathrm{g}$ under various conditions. & $\begin{array}{l}\text { - } 0.32 \text { to } 0.37 \text { at different experimental conditions } \\
\text { [19]. }\end{array}$ \\
\hline Jute fiber & $\begin{array}{l}2682,1909 \text { and } 2494 \mathrm{~m}^{2} / \mathrm{g} \text { for the samples } \\
\text { produced from bottom, middle and top part. }\end{array}$ & $\begin{array}{l}\text { - The activated carbon produced using bottom } \\
\text { part indicated the highest portion of micropores } \\
\text { if compared to other parts [20]. }\end{array}$ \\
\hline Petroleum coke & $\begin{array}{l}\text { Surface area increased from } 2209 \text { to } 2799 \mathrm{~m}^{2} / \mathrm{g} \\
\text { at lower temperature }\left(100-250^{\circ} \mathrm{C}\right) \text {, then reduced } \\
\text { to } 2205 \mathrm{~m}^{2} / \mathrm{g} \text { at } 300^{\circ} \mathrm{C} \text {. }\end{array}$ & $\begin{array}{l}\text { - Micropore volume increased }(0.96 \text { to } 1.21 \\
\left.\mathrm{cm}^{3} / \mathrm{g}\right) \text { with the increase of temperature up to } \\
250^{\circ} \mathrm{C}[21] \text {. }\end{array}$ \\
\hline
\end{tabular}




\begin{tabular}{|c|c|c|}
\hline $\begin{array}{l}\text { Soft-drink, Coca- } \\
\text { Cola }\end{array}$ & $\begin{array}{l}\text { There are different surface areas when the } \\
\text { amount of Coca-Cola added as } 3\left(1140 \mathrm{~m}^{2} / \mathrm{g}\right) \text {, } \\
3.5\left(1400 \mathrm{~m}^{2} / \mathrm{g}\right) \text { and } 4 \mathrm{~g}\left(1250 \mathrm{~m}^{2} / \mathrm{g}\right) \text {. }\end{array}$ & $\begin{array}{l}\text { - Total pore volume of activated carbon prepared } \\
\text { at } 150^{\circ} \mathrm{C} \text { is much higher }\left(2.8 \mathrm{~cm}^{3} / \mathrm{g}\right) \text { if compared } \\
\text { to } 100^{\circ} \mathrm{C}\left(1.55 \mathrm{~cm}^{3} / \mathrm{g}\right) \text { and } 130^{\circ} \mathrm{C}\left(1.75 \mathrm{~cm}^{3} / \mathrm{g}\right) \\
{[22] .}\end{array}$ \\
\hline Cactu & $\begin{array}{c}\text { Surface area of activated carbon prepared using } \\
\text { cactus increased with the impregnation rate } \\
\text { from } 0.5\left(171 \mathrm{~m}^{2} / \mathrm{g}\right), 1\left(377 \mathrm{~m}^{2} / \mathrm{g}\right) \text { and } 2(471 \\
\left.\mathrm{m}^{2} / \mathrm{g}\right) .\end{array}$ & $\begin{array}{l}\text { - Surface area was } 590,815 \text { and } 867 \mathrm{~m}^{2} / \mathrm{g} \text { with the } \\
\text { degree of impregnation rate }(0.5,1 \text { and } 2) \text { [23]. }\end{array}$ \\
\hline wood & $\begin{array}{l}\text { Higher surface area }\left(779-858 \mathrm{~m}^{2} / \mathrm{g}\right) \text { was } \\
\text { observed in the presence of nitric acid during } \\
\text { the oxidation process if compared to raw } \\
\text { activated carbon }\left(735 \mathrm{~m}^{2} / \mathrm{g}\right) .\end{array}$ & $\begin{array}{l}\text { - The samples treated with nitric acid solution } \\
\text { indicated higher percentage of mesoporous } \\
(48.9-54.7 \%)[24] \text {. }\end{array}$ \\
\hline Coconut shell & Surface area was $1916 \mathrm{~m}^{2} / \mathrm{g}$ & - $\quad$ Microporous volume was $0.25 \mathrm{~cm}^{3} / \mathrm{g}$ [25]. \\
\hline Olive tree pruning & $\begin{array}{l}\text { Surface area }\left(800-3490 \mathrm{~m}^{2} / \mathrm{g}\right) \text { strongly } \\
\text { depended on activation conditions. }\end{array}$ & $\begin{array}{l}\text { - Total pore volume is in the range of } 0.33-1.66 \\
\mathrm{~cm}^{3} / \mathrm{g} \text { for all the samples [26]. }\end{array}$ \\
\hline
\end{tabular}

Table 1: Surface area and pore characteristics of activated carbon prepared by using various raw materials.

\begin{tabular}{|c|c|c|}
\hline Adsorption & Solvent extraction & Ion exchange \\
\hline Low energy is required & Inexpensive technique & Environmental friendly technique \\
\hline Low maintenance cots is needed & Repeatable and reproducible process [27]. & Cheap maintenance \\
\hline Simplicity set up, easy operation & Simple operation [28]. & Efficient method \\
\hline Simple design & Simple apparatus & Re-usable \\
\hline Local availability & Sensitive & Cost effective \\
\hline Wide pH range & & High concentration of active sites [29]. \\
\hline High performance [30]. & & \\
\hline $\begin{array}{c}\text { Excellent remotion of components. } \\
\text { dyes in wastewater [31]. }\end{array}$ & & \\
\hline
\end{tabular}

Table 2: Several techniques of removing dye, heavy metal and pollutants from wastewater.

Chemical activator could be used during the synthesis of activated carbon (Table 3). For example, sulphuric acid, sodium hydroxide, potassium hydroxide, phosphoric acid, zinc chloride, potassium carbonate $\left(\mathrm{K}_{2} \mathrm{CO}_{3}\right)$, potassium dihydrogen phosphate $\left(\mathrm{KH}_{2} \mathrm{PO}_{4}\right)$, sodium hydroxide and potassium hydroxide play an important role during the chemical activation process. Generally, carbonization process was carried out, then single step chemical activation was done further. There are some advantages of chemical activation including reduce operation time, operational cost, energy consumption, and production with higher efficiency could be seen. Researcher reported that great improvement could be observed such as encourage production of crosslink, limit the production of volatile compounds, and dissolve the cellulosic component during the chemical activation and dehydrogenation capability of material. Up-to-date, the influence of impregnation ratio has been reported by many researchers. It is described as the weight of chemical activator (in grams) to the weight of dried carbon used.

\begin{tabular}{|c|c|}
\hline Activator & Highlighted Results \\
\hline $\mathrm{ZnCl}_{2}$ & 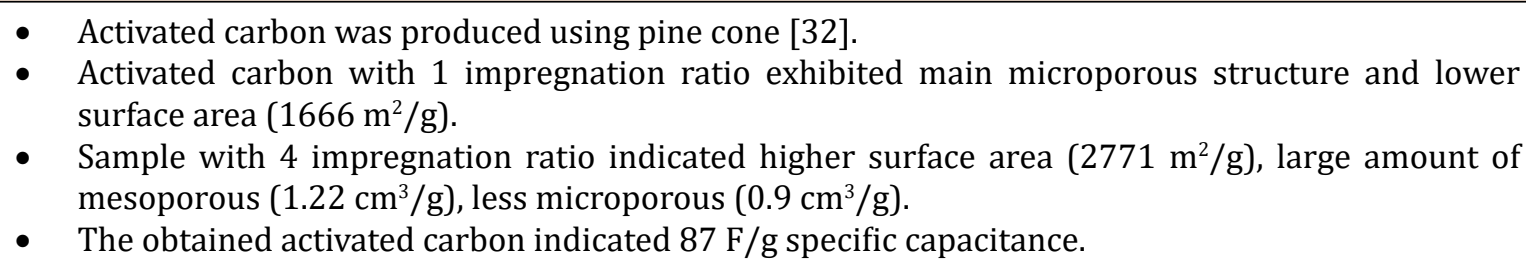 \\
\hline
\end{tabular}




\begin{tabular}{|c|c|}
\hline $\mathrm{ZnCl}_{2}$ & $\begin{array}{l}\text { - Activated carbon prepared using Arundo donax in the presence of activator [33]. } \\
\text { - Sample yields reduced with an increase in impregnation ratios from } 0.5 \text { to } 3 \text { at carbonization } \\
\text { temperature of } 300^{\circ} \mathrm{C} \text {. } \\
\text { - The best impregnation ratio was } 1.5 \text {, and produced the highest surface area }\left(1874 \mathrm{~m}^{2} / \mathrm{g}\right) \text {. }\end{array}$ \\
\hline $\begin{array}{c}\mathrm{ZnCl}_{2}, \mathrm{~K}_{2} \mathrm{CO}_{3} \\
\mathrm{KH}_{2} \mathrm{PO}_{4}\end{array}$ & $\begin{array}{l}\text { - There are several chemical activators were used to produce activated carbon from tamarind seed } \\
\text { - } 34] \text {. } \\
\text { - compativat carbon prepared using zinc chloride has the highest percentage }(39.18 \%) \text { of yield if } \\
\text { - Zinc chloride is the best activator, and often used as activating agent for green precursor. } \\
\text { - The carbon prepared using zinc chloride showed the highest iodine number and porosity as well. }\end{array}$ \\
\hline Zinc chloride & $\begin{array}{l}\text { - Sunflower seed husk was used as raw material to produce activated carbon [35]. } \\
\text { - Iodine number increased (1221 }-1545 \mathrm{mg} / \mathrm{g}) \text { with increasing of impregnation ratio from } 0.5: 1,1: 1 \\
\text { and } 1.5: 1 \text {. } \\
\text { The best impregnation ratio was } 1: 1 \text {, which produced the highest surface area }\left(1511 \mathrm{~m}^{2} / \mathrm{g}\right) \text { and } \\
\text { total pore volume }\left(0.35 \mathrm{~cm}^{3} / \mathrm{g}\right) \text {. }\end{array}$ \\
\hline Phosphoric acid & $\begin{array}{l}\text { - The influence of phosphoric acid concentration was studied from } 36 \text { to } 85 \mathrm{wt} \% \text {. } \\
\text { - The obtained results show the best concentration was } 36 \% \text { for the activated. carbon prepared } \\
\text { using chestnut, cedar and walnut wood [36]. }\end{array}$ \\
\hline $\mathrm{KOH}$ & $\begin{array}{l}\text { - Fir wood was used to synthesize activated carbon [37]. } \\
\left.\text { - Surface area (891-2794 } \mathrm{m}^{2} / \mathrm{g}\right) \text { and fraction of micropore volume (0.76-0.82) are strongly depended } \\
\text { on } \mathrm{KOH} / \text { sample ratio from } 0.5 \text { to } 6 \text {. }\end{array}$ \\
\hline $\mathrm{KOH}, \mathrm{H}_{3} \mathrm{PO}_{4}$ & $\begin{array}{l}\text { - Wood was employed as raw material } \\
\text { - The adsorption of chromium (VI) ions was higher in } \mathrm{KOH} \text {-activated carbon if compared to } \mathrm{H}_{3} \mathrm{PO}_{4} \\
\text { activated carbon [38]. }\end{array}$ \\
\hline $\mathrm{H}_{3} \mathrm{PO}_{4}$ & $\begin{array}{l}\text { - C. schweinfurthii nutshell was utilized to prepare activated carbon [39]. } \\
\text { - Large amount of carbon (88.6\%) could be observed indicating phosphoric acid retain carbon and } \\
\text { to prevent loss of other volatile material. } \\
\text { - Results reflected that yield increases with impregnation ratio (40-60\%), temperature (200- } 400 \\
{ }^{\circ} \text { C) and time (20 to } 60 \text { minutes). } \\
\text { - Increased in concentration of activator, leads to enlarge the pores, and improve the adsorption } \\
\text { capacity. }\end{array}$ \\
\hline Sulfuric acid & $\begin{array}{l}\text { - } \quad \text { Activated carbon was produced using sal wood [40]. } \\
\text { - The highest decolorizing power }(27 \mathrm{mg} / \mathrm{g}) \text { could be observed as the impregnation ratio was } 0.75 \text {. } \\
\text { Surface area increased }\left(1012-2279 \mathrm{~m}^{2} / \mathrm{g}\right) \text { as the impregnation ratio was increased from } 0.25 \text { to } \\
0.75 \text {. }\end{array}$ \\
\hline Sulfuric acid & $\begin{array}{l}\text { - Orange peel was used to produce activated carbon. } \\
\text { - } \quad \text { Carbon prepared using activator showed higher surface area }\left(1934 \mathrm{~m}^{2} / \mathrm{g} \text { ) and well-developed pore. }\right. \\
\text { - Total pore volume and surface area were strongly depended on impregnation time. }\end{array}$ \\
\hline Sulfuric acid & $\begin{array}{l}\text { - Sunflower oil cake was employed to prepare activated carbon [41]. } \\
\text { - AC1, AC } 2 \text { and AC } 3 \text { represented impregnation ratio of } 0,0.85 \text { ad } 1.9 \text {, respectively. } \\
\text { - Specific surface area, total pore volume and micropore area are found to be } 8.8 \mathrm{~m}^{2} / \mathrm{g}, 0.0063 \mathrm{~cm}^{3} / \mathrm{g} \\
\text { and } 8.26 \mathrm{~m}^{2} / \mathrm{g} \text { in AC } 1 \text {. }\end{array}$ \\
\hline
\end{tabular}




\begin{tabular}{|c|c|}
\hline $\mathrm{KOH}, \mathrm{K}_{2} \mathrm{CO}_{3}$ & $\begin{array}{l}\text { - Soy bean oil cake was used to synthesis activated carbon at } 800{ }^{\circ} \mathrm{C} \text { using } \mathrm{KOH} \text { (impregnation ratio } \\
\text { of } 1) \\
\text { - This raw material is considered as cheap lignocellulosic materials } \\
\text { - Higher surface area could be produced by using } \mathrm{K}_{2} \mathrm{CO}_{3}\left(1352.9 \mathrm{~m}^{2} / \mathrm{g}\right) \text { if compared to } \mathrm{KOH} \text { at } 800^{\circ} \mathrm{C} \text {. } \\
\text { - Higher ash and Sulphur content could be observed for the sample impregnated with } \mathrm{KOH}[43] \text {. }\end{array}$ \\
\hline $\mathrm{KOH}, \mathrm{K}_{2} \mathrm{CO}_{3}$ & $\begin{array}{l}\text { - Grape seed was used to synthesis activated carbon by using different activators [44]. } \\
\text { - The results are mainly microporous, but various surface area if using } 25 \% \mathrm{KOH}\left(1222 \mathrm{~m}^{2} / \mathrm{g}\right) \text { and } \\
50 \% \mathrm{~K}_{2} \mathrm{CO}_{3}\left(1238 \mathrm{~m}^{2} / \mathrm{g}\right) \text {. } \\
\text { - Higher yield could be observed at } 600{ }^{\circ} \mathrm{C} \text { if compared to } 800{ }^{\circ} \mathrm{C} \text { for both activators. }\end{array}$ \\
\hline $\mathrm{KOH}$ & $\begin{array}{l}\text { - Rice straw was used to produce activate carbon via carbonization and activation method [45]. } \\
\text { - High methylene blue adsorption, high yield, and high surface area }\left(1917 \mathrm{~m}^{2} / \mathrm{g}\right) \text { could be obtained } \\
\text { after these two steps. }\end{array}$ \\
\hline Phosphoric acid & $\begin{array}{l}\text { - Coconut shell was used to prepared activated carbon [46]. } \\
\text { - Sample impregnated with } 0.25 \mathrm{M} \text { of phosphoric acid can improve toluene (95.8 to } 98.1 \% \text { ) and } \\
\text { isopropanol ( } 95.2 \text { to } 97.2 \% \text { ) removal efficiency. } \\
\text { - Surface area reduced from } 724.9 \text { to } 240.5 \mathrm{~m}^{2} / \mathrm{g} \text { as the concentration of phosphoric was increased } \\
(0.25 \text { to } 3 \mathrm{M} \text { ) indicating activator occupied the pores. }\end{array}$ \\
\hline $\mathrm{NaOH}$ & $\begin{array}{l}\text { - Activated carbon produced using rice husk under various activation temperatures [47]. } \\
\text { - FTIR spectra revealed that formed basic group such as carbonyl and quinone at higher activation } \\
\text { temperature. } \\
\text { - The films prepared at } 800{ }^{\circ} \mathrm{C} \text { showed the highest amount of basic group, could be used in } \\
\text { - Supercapacitor applications. } \\
\text { - Surface area and total pore volume varies } 2482-2681 \mathrm{~m}^{2} / \mathrm{g} \text { and } 1.2929-1.4016 \mathrm{~cm}^{3} / \mathrm{g} \text {. }\end{array}$ \\
\hline $\mathrm{NaOH}$ & $\begin{array}{l}\text { - Coconut shell was used to produce activated carbon under various impregnation ratios such as 1:1, } \\
\text { 2:1 and 3:1. } \\
\text { - Surface area (783 to } 2825 \mathrm{~m}^{2} / \mathrm{g} \text { ) increased with increasing impregnation ratio [48]. }\end{array}$ \\
\hline
\end{tabular}

Table 3: Several chemical activators have been used to prepare activated carbon.

\section{Metal Chalcogenide Thin Films}

Thin films have received great attention due to good chemical, physical [49], optical and electrical properties. The obtained films have been used in many applications such as gas sensing, solar cell [50], sensor device, laser device, energy conversion, energy storage and field-effect transistors. There are many deposition techniques have been used to prepare thin films. Basically, these deposition techniques could be divided into physical or chemical method. Research findings supported that each of these techniques has benefit and limitation as well. Quality and properties of films strongly depended onto deposition method as well [51].

Atomic layer deposition could be used to synthesis thin films. This deposition technique has many advantages including produce pin hole free morphology, synthesis films at low temperature, control film thickness easily and high aspect ratio coating. Basically, thin films are slowly formed from different precursors on substrate. For example, "first raw material" is adsorbed on the surface of substrate in order to form monolayer as shown in Figure 1. Then, any excess (first raw material) is removed. "Second raw material" is added and reacted with "first raw material" to form layer on the surface of substrate. Following that, "second raw material" is cleared from the reaction chamber. This process is repeated until reach desired thickness.

Single phase copper sulphide films have been prepared at $140-160{ }^{\circ} \mathrm{C}$ in the presence of solid sulphur and copper acetylacetonate. These sample are p-type films, band gap values in the ranges of 2.4 to $2.54 \mathrm{eV}$. Higher growth arte and flake like morphology could be observed when the temperature was increased above $160^{\circ} \mathrm{C}$ [52]. $\mathrm{H}_{2} \mathrm{~S}$ was used to provide sulphur ion [53] during the deposition process at 130 to $200^{\circ} \mathrm{C}$. Optical properties show that direct ( 2.2 to $\left.2.5 \mathrm{eV}\right)$ and indirect band gap (1.6 to $1.8 \mathrm{eV}$ ) could be found. Growth of $\mathrm{Bi}_{2} \mathrm{Se}_{3}$ films have been prepared in the presence of $\mathrm{Na}_{2} \mathrm{SeO}_{3}$ and $\mathrm{Bi}\left(\mathrm{NO}_{3}\right)_{3}$ solution. The sphalerite $\mathrm{ZnSe}$ films have been prepared on different substrates [54]. ZnSe thin films could be used in white light emitting electroluminescence displays. ZnS films are prepared using hydrogen sulphide and diethyl zinc in $200-350^{\circ} \mathrm{C}$ [55]. The film growth is depended on various conditions such as temperature and purge times. Tin selenide thin films are $p$-type conductance, have hole mobility of $10 \mathrm{~cm}^{2} /$ V.s and $\mathrm{I}_{\text {on }} / \mathrm{I}_{\text {off }}$ ratio of $10^{5}$. Orthorhombic 
structure and smooth morphology are observed [42]. Copper indium sulphide films have been grown onto substrate in the presence of $\mathrm{CuCl}, \mathrm{InCl}_{3}$ and $\mathrm{H}_{2} \mathrm{~S}[56]$ at $380^{\circ} \mathrm{C}$. The materials were used to absorber in solar cell device with conversion efficiencies up to $2.8 \%$.

$$
\text { Second raw material }
$$

First raw material

Substrate

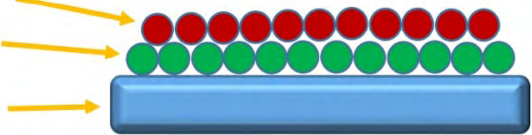

Figure 1: Atomic layer deposition technique.

Chemical bath deposition method is considered as costeffective method to produce polycrystalline films under larger scale deposition. The obtained films are quite stable, however, strongly depended on experimental conditions such as $\mathrm{pH}$, concentration of solution, deposition time, complexing agent. The presence of complexing agent improves the quality of thin films. This technique has simple experimental setup. Chemical bath contains metal ion and chalcogen ion solution, $\mathrm{pH}$ meter and substrate. During the deposition process, substrate will be immersed into chemical bath. There are two processes could be observed in this method. Formation of films occurred by sequential ionic reactions under ion-by-ion process. Another process called cluster process, where colloidal particles are absorbed at the substrate surface to produce layer.

Copper sulphide thin films were prepared in the presence of amino acid [57]. Morphology and structure studies showed the nanoflake particle with hexagonal structure of complexing agent (amino acid). Thin films produced by using alanine, glycine and serine, showed thickness of 42, 55.4 and $70 \mathrm{~nm}$ respectively. Chemical bath deposition of lead selenide in the presence of tri-sodium citrate as described [58]. Researchers explain that thickness increased in longer deposition time (5 hours), indicating complexing agent can control $\mathrm{Pb}^{2+}$ ions during the experiment. XRD data showed that the films synthesized for 4 and 5 hours have more diffraction peaks and higher intensities. $\mathrm{AgAlS}_{2}$ films have been produced using silver nitrate, aluminium sulphate, thiourea and EDTA (complexing agent). Film thickness increased from $0.03 \mu \mathrm{m}$ to $0.52 \mu \mathrm{m}$ in longer deposition time [59]. The obtained band gap values are in the range of 2.15 to $2.4 \mathrm{eV}$. Preparation of tin sulphide thin films by using stannous chloride, thioacetimide and tartaric acid. Formation of complex ion was observed, $\mathrm{Sn}^{2+}$ ions combined with $\mathrm{S}^{2-}$ ions to form SnS films. The films prepared at $70^{\circ} \mathrm{C}$ show high optical conductivity, low loss of power, absorption edge was shifted to longer wavelength [60]. The quartz was used as substrate in order to prepare $\mathrm{ZnS}$ films by using $\mathrm{NH}_{4} \mathrm{OH}$. Thickness of $200 \mathrm{~nm}$ have been produced, and could be used in optoelectronic applications. Energy dispersive
X-ray analysis results supported that ratio 1:1.1 (Zn:S) for all samples [61]. Chemical bath deposited $\mathrm{CdS}_{0.5} \mathrm{Se}_{0.5}$ films were used in temperature sensor, holography, and optical waveguide. Visual observation indicated the yellowish orange films were synthesized onto non-conducting glass substrate. Complexing agent such as 8hydroxyquinoline was used to control release $\mathrm{Cd}^{2+}$ ions slowly. An increase of the crystalline size leads to decrease in the electrical resistivity [62].

Cadmium selenide thin films could be used in electronic, optoelectronic and photovoltaic. Deposition was carried out onto soda lime glass in the presence of ammonia. The zinc blende structure and band gap (1.8 to $1.9 \mathrm{eV}$ ) were observed for all the samples prepared using cadmium chloride and sodium selenosulphate. Morphology studies indicated bigger grain could be seen when the concentration of ammonia $(0.4$ to $0.8 \mathrm{M}$ ) was increased [63].

Electrodeposition is an example of chemical deposition technique. Thin films could be synthesized by using electro deposition method at room temperature. This technique is considered as low cost and large scale deposition could be carried out. Commonly, it involves the reduction of metallic ions that are produced from the electrolyte. Complexing agent plays an important role in order to bring the reduction potentials of the individual elements closer.

Stainless steel was used as substrate to prepare cadmium selenide films by using ethylenediaminetetraacetic acid (EDTA). The obtained CdSe films show n-type conductivity [64]. CdSe could be used in solar cell application. The obtained fill factor and power conversion efficiency were 0.31 and $0.34 \%$, respectively. Cadmium sulphide films were deposited onto $\mathrm{Au}$ (111) substrate [65] under various $\mathrm{pH}$ values in the presence of EDTA. Structure studies show the formation of the cubic $(\mathrm{pH} 5)$ and hexagonal structure (pH 4). The growth of $\mathrm{Sb}_{2} \mathrm{Se}_{3}$ films at different deposition potentials by using citric acid [66]. Energy dispersive X-ray analysis data supported that the films prepared at -0.8 and $-1 \mathrm{~V}$ (versus Saturated Calomel Electrode), displayed atomic composition close to 40:60.

The CuInSe ${ }_{2}$ thin films were prepared by using sodium citrate [67]. When the concentration of complexing agent was increased, cathodic shifts of the selenium and copper were observed. Further, researchers explain that citrate ions do not change the indium potential but improves its crystallinity. Nanostructured $\mathrm{AgInSe}_{2}$ thin films were deposited onto different substrates such as molybdenum/ glass and ITO glass [68] by using potassium thiocyanate (KSCN). XRD data showed the strongest peak corresponded to (112) plane of tetragonal chalcopyrite structure. Optical properties revealed that the obtained films covered the 
whole visible range, and transparent in the near infrared region. The KSCN was used as complexing agent during the deposition process in order to produce $\mathrm{CuInSe}_{2}$ thin films [69]. The electrolytic bath contains $\mathrm{Cu}^{+}, \mathrm{In}^{3+}, \mathrm{Se}^{4+}$ ions and thiocyanate ions. Ternary compound such as Cd-Fe-S films were synthesized by using $\mathrm{Na}_{2}$ EDTA (ethylenediamine tetra acetic acid disodium) [70]. Band gap value strongly depended (from 2.43 to $0.81 \mathrm{eV}$ ) on the content of iron from 0 to 1 . Based on the experimental results, the best content was when $x=0.2$. Because of these films are more photosensitive than other compositions. HgCdTe thin films were deposited onto $\mathrm{SnO}_{2}$ coated glass substrate by using acetonitrile [71], $\mathrm{CdCl}_{2}, \mathrm{HgCl}_{2}$ and Te reacted with nitric acid. No deposition could be observed without complexing agent. The films prepared under complexing agent indicated the sharp peak corresponded to (111) plane. These films are polycrystalline with cubic structure. According to experimental findings, the best stoichiometry was observed when the composition, $\mathrm{x}=0.15,0.3$ and 0.6 at deposition potential of $0.65,0.7$ and $0.75 \mathrm{~V}$ (versus saturated calomel electrode). Nanostructured CdZnTe films were prepared using acetonitrile under different deposition potentials [72]. Uniform morphology with grain size of $1 \mu \mathrm{m}$ could be seen for the films prepared at deposition potential of $-0.5 \mathrm{~V}$. Scanning electron microscopy studies revealed that grain size reduces with increasing in deposition potential. Electrical studies indicated n-type and p-type could be observed in as-deposited film and annealed films, respectively.

Quaternary $\mathrm{Cu}_{2} \mathrm{ZnSnS}_{4}$ films were deposited onto Mocoated soda lime glass substrates at room temperature [73]. The films are nearly stoichiometric when $25 \mathrm{~mL}$ of complexing agent were used. Field emission scanning electron microscopy [FESEM] revealed that grain size reduces when the volume of tri-sodium citrate was increased.

\section{Conclusion}

Experimental results showed there are several raw materials could be used to produce activated carbon under carbonization and activation process. The obtained activated carbon showed higher surface area and porosity structure in the presence of chemical activator. Metal chalcogenide thin films have been synthesized by using various techniques. Research findings indicated these material could be employed in solar cell, sensor, laser and optoelectronic applications.

\section{Acknowledgment}

The author would like to thank INTI INTERNATIONAL UNIVERSITY for financial support.

\section{References}

1. Ramonna I, Athanasios C, George ZK (2019) Synthesis of activated carbon from food waste. Environmental Chemistry Letters 17: 429-438.

2. Habila MA, Ahmed AS, Sheikh M, Zeid AA, Ahmed AA, et al. (2019) Phosphonium based ionic liquid modified activated carbon from mixed recyclable waste for mercury (II) uptake. Molecules, 24(3): 570.

3. Joana MD, Maria CM, Manuel FA, Jose RU, Manuel SP (2007) Waste materials for activated carbon preparation and its use in aqueous-phase treatment: A review. Journal of Environment Management 85(4): 833-846.

4. Jaria G, Vania C, Carla PS, Maria V, Marta O (2019) Obtaining granular activated carbon from paper mill sludge- a challenger for application in the removal of pharmaceuticals from wastewater. Sci Total Environ 653: 393-400.

5. Gamzenur O, Murat K, Esin A, Ayse EP (2019) Chemically activated carbon production from agricultural waste of chickpea and its application for heavy metal adsorption: equilibrium, kinetic and thermodynamic studies. Applied Water Science 9.

6. Ho SM (2016) Optical properties of ternary thin films $\left(\mathrm{Ni}_{3} \mathrm{~Pb}_{2} \mathrm{~S}_{2}\right)$ prepared by chemical bath deposition technique. Research Journal of Chemistry and Environment 20: 29-33.

7. Deepank S, Prashantkumar G, Sipra C, Betty C (2019) Chalcogenide thin film multilayer structure for solar cell applications. Vacuum 159: 141-143.

8. Ho SM (2017) Growth and characterization of CuInTe thin films: Review. Journal of Engineering and Applied Sciences 12(14): 3720-3723.

9. Daniela EO, Arturo IM, Luis AG (2019) CuS films grown by a chemical bath deposition process with amino acids as complexing agents. Materials Science in Semiconductor Processing 89: 18-25.

10. Ho SM, Muhammad BT, Das SN, Das MR (2019) Preparation of thin films by SILAR and Spin coating method. Eurasian Journal of Analytical Chemistry 14: 165-172.

11. Ying Z, Song X, Yue X, Shen H, Kong X, et al. (2019) Utilization of wheat bran for producing activated carbon with high specific surface area via $\mathrm{NaOH}$ activation using industrial furnace. Journal of Cleaner Production 210: 366-375.

12. Oginni O, Singh K, Gloria O, Benjamin D, Louis M, et al. (2019) Influence of one step and two step KOH activation on activated carbon characteristics. Bio resource 
Technology Reports 7.

13. Yun Y, Ning Q, Wang D, Zhu Q, Fu F, et al. (2019) Fluffy honey comb like activated carbon from popcorn with high surface area and well developed porosity for ultrahigh efficiency adsorption of organic dyes. Bio resource Technology 285.

14. Duan X, Yuan C, Jing T, Yuan X (2019) Removal of elemental mercury using large surface area micro-porous corn cob activated carbon by zinc chloride activation. Fuel 239: 830-840.

15. Asma N, Bahruddin S, Bhat A, Khan AS, Danish, M, et al. (2019) Mangosteen peel waste as a sustainable precursor for high surface area mesoporous activated carbon: characterization and application for methylene blue removal. Journal of Cleaner Production 211: 11901200.

16. Qu W, Yuan T, Yin G, Xu S, Su H, et al. (2019) Effect of properties of activated carbon on malachite green adsorption. Fuel 249(1): 45-53.

17. Negara D, Nindhia $T$, Surata I, Hidajat F, Made $S$ (2019) Nanopore structures, surface morphology and adsorption capacity of tabah bamboo activated carbons. Surfaces and Interfaces 16: 22-28.

18. Sai SS, Sandhya RM, Ramaprabhu S (2019) Investigation of room temperature hydrogen storage in biomass derived activated carbon. Journal of Alloys and Compounds 789: 800-804.

19. Ahmed MB, Johir MB, Zhou JL, Ngo HH, Long D (2019) Activated carbon preparation from biomass feedstock: clean production and carbon dioxide adsorption. Journal of Cleaner Production 225: 405-413.

20. Junayet HK, Freddy M, Young C, Lin J, Tofazzal M (2019) Jute-derived microporous/mesoporous carbon with ultra-high surface area using a chemical activation process. Microporous and Mesoporous Materials 274(15): 251-256.

21. Wang W, Xu S, Wang K, Liang J, Zhang W (2019) Deintercalation of the intercalated potassium in the preparation of activated carbons by $\mathrm{KOH}$ activation. Fuel Processing Technology 189: 74-79.

22. Stalin J, Kempaiah DM, Mercy RB, Hamid I, Singh G, et al. (2019) Highly ordered mesoporous carbons with high specific surface area from carbonated soft drink for supercapacitor application. Microporous and Mesoporous Materials 280:337-346.

23. Mourad O, Lamyae L, Safa M, Nadia H, Mohamed B
(2019) Valorisation of cellulosic waste basic cactus to prepare activated carbon. Journal of the Saudi Society of Agricultural Sciences 18(2): 133-140.

24. Reyers J, Reyers RB, Garcia A, Soto E, Cerino F (2019) Adsorption mechanisms of hexavalent chromium from aqueous solutions on modified activated carbon. Journal of Environmental Management 236: 815-822.

25. Feng Y, Ji W, Liu Y, Zheng Q (2019) Adsorption equilibrium of hydrogen adsorption on activated carbon, multi-walled carbon nanotubes and graphene sheets. Cryogenics 101: 36-42.

26. Arminda M, Maria F, Marianela G, Deiana C (2019) Highly microporous carbons from olive tree pruning: optimization of chemical activation conditions. Journal of Environmental Chemical Engineering 7(1).

27. Yang C, Yu Q, Zhang L, Feng J (2006) Solvent extraction process development and on-site trial plant for phenol removal from industrial coal gasification wastewater. Chemical Engineering Journal 117(2): 179-185.

28. Antonio N, Borrull F, Eva P, Rosa MM (2010) Pressurized liquid extraction: a useful technique to extract pharmaceuticals and personal care products from sewage sludge. TrAC Trends in Analytical Chemistry 29(7): 752-764.

29. Sanjay KS, Rashmi S (2012) Advances in water treatment and pollution prevention. Springer, Berlin.

30. Athar H, Ahmed S (2019) Advanced treatment techniques for industrial wastewater. IGI Global, Hershey.

31. Eric L, Jan S, Didier R (2012) Environmental chemistry for a sustainable world. Volume 2, Remediation of air and water pollution, Springer, Berlin.

32. Kose KO, Piskin B, Mehmet KA (2018) Chemical and structural optimization of $\mathrm{ZnCl}_{2}$ activated carbons via high temperature $\mathrm{CO}_{2}$ treatment for EDLC applications. International Journal of Hydrogen Energy 43(40): 18607-18616.

33. Osman U, Yuksel B (2018) The effect of carbonization temperature, carbonization time and impregnation ratio on the properties of activated carbon produced from Arundo donax. Microporous and Mesoporous Materials 268(15): 225-234.

34. Jeyashelly A, Nur A, Satar A (2018) Synthesis and characterization of Tamarind seed activated carbon using different types of activated agents: A comparison study. Materials Today: Proceedings 5(9): 17611-17617. 
35. Orhan B, Omer S, Saka C (2018) Sequential application of microwave and conventional heating methods for preparation of activated carbon from biomass and its methylene blue adsorption. Applied Thermal Engineering 138(25): 542-551.

36. Diez MA, Gomez V, Fernandez C, Correa EM, Garcia A (2004) Porous texture of activated carbons prepared by phosphoric acid activation of woods. Applied Surface Science 238(1-4): 309-313.

37. Wu F, Tseng R, Juang R (2005) Preparation of highly microporous carbons from fir wood by $\mathrm{KOH}$ activation for adsorption of dyes and phenols from water. Separation and Purification Technology 47(1-2): 10-19.

38. Khezami L, Richard C (2005) Removal of chromium (VI) from aqueous solution by activated carbons: kinetic and equilibrium studies. Journal of Hazardous Materials 123(1-3): 223-231.

39. Adegboyega SO, Ajayi OA, Michael SO, Mku TI, Sam SA (2015) Preparation of phosphoric acid activated carbons from canarium schweinfurthii nutshell and its role in methylene blue adsorption. Journal of Chemical Engineering and Materials Science 6(2): 9-14.

40. John, U, Murthy Z (2009) Removal of $\mathrm{Pb}$ (II) from aqueous solutions by carbons prepared from Sal wood (Shorea robusta). European Journal of Wood and Wood Products 7(2): 197-206.

41. Selhan K, Tay T, Suat U, Murat E (2008) Activated carbons from waste biomass by sulfuric acid activation and their use on methylene blue adsorption. Bio resource Technology 99(14): 6214-6222.

42. Afrin S, Neal K, Raj S (2018) Atomic layer deposition of 2-dimensional, semiconducting SnSe thin films. 2018 IEEE $13^{\text {th }}$ Nanotechnology Materials and devices conference (NMDC), Portland, OR, USA.

43. Karagoz S, Ucar S, Tay $\mathrm{T}$ (2009) Preparation and characterization of activated carbon from waste biomass. Journal of Hazardous Materials 165(1-3): 481-485.

44. Irem O, Selhan K, Turgay T, Murat E (2014) Activated carbons from grape seeds by chemical activation with potassium carbonate and potassium hydroxide. Applied Surface Science 293: 138-142.

45. Basta AH, Fierro V, Celzard A, El H (2009) 2-steps KOH activation of rice straw: an efficient method for preparing high performance activated carbons. Bioresource Technology 100(17): 3941-3847.

46. Kang, YH, Shiue A, Hu SC, Huang CY, Chen H (2010)
Using phosphoric acid impregnated activated carbon to improve the efficiency of chemical filters for the removal of airborne molecular contaminants (AMCs) in the make-up air unit (MAU) of a cleanroom. Building and Environment 45(4): 929-935.

47. Khu LV, Thu T (2014) Activated carbon derived from rice husk by $\mathrm{NaOH}$ activation and its application in supercapacitor. Progress in Natural Science: Materials International 24(3): 191-198.

48. Andre L, Alexandro M, Eurica M, Vitor C (2011) $\mathrm{NaOH}$ activated carbon of high surface area produced from coconut shell: kinetics and equilibrium studies from the methylene blue adsorption. The Chemical Engineering Journal 174(1): 117-125.

49. Kassim A, Tan WT, Saravanan N, Ho SM (2010) The effect of bath temperature on the chemical bath deposition of copper sulphide thin films. Jordan Journal of Chemistry 5(2): 165-173.

50. Anuar K, Ho SM, Tee TW, Nagalingam S, Kuang D, et al. (2009) Effects of $\mathrm{pH}$ value on the electro deposition of $\mathrm{Cu}_{4} \mathrm{SnS}_{4}$ thin films. Analele Universitatii Bucuresti Chimie 18(1): 59-64.

51. Saravanan N, Anuar K, Ho SM, Atan S (2010) Influence of triethanolamine on the properties of chemical bath deposited nickel sulphide thin films. Jurnal Nanosains \& Nanoteknologi 3: 22-24.

52. Tripurari S, Jouko L, Maarit K (2018) Atomic layer deposition of conducting CuS thin films from elemental sulphur. Advanced Materials Interfaces 5(9).

53. Nathanaella S, Daniel L, Donsanti F (2016) Atomic layer deposition of copper sulphide thin films. Thin Solid Films 600(1): 103-108.

54. Guziewicz E, Kopalko K, Lusakowska E, Mattew RP (2004) Atomic layer deposition of thin films of ZnSe structural and optical characterization. Thin Solid Films 446(2): 172-177.

55. Gert S, Patrick M, Andriy H, Neyts K (2002) Atomic layer deposition of ZnS thin films based on diethyl zinc and hydrogen sulphide. Journal of Crystal Growth 234(4): 690-698.

56. Nathanaelle S, Muriel B, Pascal G, Daniel L, Frederique D (2015) Deposition of ultra-thin $\mathrm{CuInS}_{2}$ absorber layers by ALD for thin film solar cells at low temperature (down to $\left.150^{\circ} \mathrm{C}\right)$. Nanotechnology $26(5)$.

57. Daniel T, Nishanthi ST, Mohanraj K, Sivakumar G (2019) Influence of film thickness variation on the photo electro 
chemical cell performancesAgg $\mathrm{SbS}_{3}$ thin films. Vacuum 161: 138-142.

58. Sharmistha A, Mausumi P, Mishra BK, Shahid A (2015) Effect of deposition time on lead selenide thermoelectric thin films prepared by chemical bath deposition technique. Materials Science in Semiconductor Processing 34: 45-51.

59. Ezeobele EE, Ezenwa IA (2015) Optical properties of silver aluminium sulphide ternary thin films deposited by chemical bath method. International Journal of Science and Technology 4(1): 45-57.

60. Gedi S, Reddy V, Park C, Jeon C, Ramakrishna R (2015) Comprehensive optical studies on SnS layers synthesized by chemical bath deposition. Optical Materials 42: 468475.

61. Taisuke I,Ando S (2012) Preparation and characterization of $\mathrm{ZnS}$ thin films by the chemical bath deposition method. Thin Solid Films 520(24): 7076-7082.

62. Khomane AS (2013) Crystallographic and microscopic properties of ternary $\mathrm{CdS}_{0.5} \mathrm{Se}_{0.5}$ thin films. Optik 124(16): 2432-2435.

63. Yu Z, Yan Z, Liu J, Wei A (2013) Synthesis and characterization of CdSe nanocrystal line thin films deposited by chemical bath deposition. Materials Science in Semiconductor Processing 16(6): 1592-1598.

64. Pawar SM, Moholkar AV, Rajpure KY, Bhosale CH (2008) Photoelectrochemical investigations on electrochemically deposited CdSe and Fe-doped CdSe thin films. Solar Energy Materials \& Solar Cells 92(1): 45-49.

65. Sisman I, Alanyahoglu M, Demir U (2007) Atom-byatom growth of CdS thin films by an electrochemical co-deposition method: Effects of pH on the growth mechanism and structure. J Phys Chem C 111(6): 26702674.

66. Fernandez AM, Merino MG (2000) Preparation and characterization of $\mathrm{Sb}_{2} \mathrm{Se}_{3}$ thin films prepared by electrodeposition for photovoltaic applications. Thin Solid Films 366(1-2): 202-206.

67. Chraibi F, Fahoume M, Ennaoui A, Delplancke JL (2001) Influence of citrate ions as complexing agent for electro deposition of $\mathrm{CuInSe}_{2}$ thin films. Physica Status Solidi A 186(3): 373-381.

68. Aouaj MA, Diaz R, Moursli FCE, Silver AT, et al. (2015) $\mathrm{AgInSe}_{2}$ thin films prepared by electrodeposition process. International Journal of Materials Science and Applications 4(1): 35-38.

69. Tzvetkova E, Stratieva N, Ganchev M, Tomov I, Ivanova $\mathrm{K}$, et al. (1997) Preparation and structure of annealed $\mathrm{CuInSe}_{2}$ electro deposited films. Thin Solid Films 311(12): 101-106.

70. Deshmukh SK, Kokate AV, Sathe DJ (2005) Studies on electro deposited $\mathrm{Cd}_{1-\mathrm{x}} \mathrm{Fe}_{\mathrm{x}} \mathrm{S}$ thin films. Materials Science and Engineering B 122(3): 206-210.

71. Chauhan S, Rajaram P (2008) Electrodeposition of HgCdTe thin films. Solar Energy Materials and Solar Cells 92(5): 550-557.

72. Bansal A, Rajaram P (2005) Electrochemical growth of CdZnTe thin films. Materials Letters 59(28): 3666-3671.

73. Jeon M, Tanaka, Y, Shimizu T, Shingubara S (2011) Formation and characterization of single step electrodeposited $\mathrm{Cu}_{2} \mathrm{ZnSnS}_{4}$ thin films: Effect of complexing agent volume. Energy Procedia 10: 255-260. 